\title{
Isolation and Characterization of Antitumor Alkaloid from Poppy Capsules (Papaver somniferum)
}

\author{
Ibrahim Bulduk ${ }^{1}$ and Fulya Taktak ${ }^{2}$ \\ ${ }^{1}$ Department of Chemistry, University of Uşak, 64200 Uşak, Turkey \\ ${ }^{2}$ Department of Chemical Engineering, University of Uşak, 64200 Uşak, Turkey \\ Correspondence should be addressed to Fulya Taktak; fulya.taktak@usak.edu.tr
}

Received 17 May 2012; Accepted 30 July 2012

Academic Editor: Malgorzata Baranska

Copyright ( 2013 I. Bulduk and F. Taktak. This is an open access article distributed under the Creative Commons Attribution License, which permits unrestricted use, distribution, and reproduction in any medium, provided the original work is properly cited.

Noscapine, a phthalideisoquinoline alkaloid derived from opium, has been used in the treatment of various cancer types. Its lowtoxicity profile has increased attention to this alkaloid. With regard to increasing demand for this compound, we developed a new method for isolation of noscapine from dried capsules of Papaver somniferum. Noscapine was successfully isolated from poppy capsules for the first time and the purity of the isolated compound was determined to be over 99.59\% by HPLC analysis. The structure of noscapine was confirmed by ${ }^{1} \mathrm{H}$ NMR, ${ }^{13} \mathrm{C}$ NMR, FT-IR, elemental analysis, and HR-ESI-MS methods.

\section{Introduction}

Important class of pharmaceutical compounds, they are alkaloids form, which can be found in natural products such as the opium poppy, Papaver somniferum. Alkaloids are normally removed from natural products using solvent extraction. However, the extraction of very small quantities of alkaloids in natural plants required the development of new and improved experimental methods. Noscapine, (3S)6,7-Dimethoxy-3-[(5R)-4-methoxy-6-methyl-5,6,7,8-tetrahydro-1,3-dioxolo[4,5-g] isoquinolin-5-yl] isobenzofuran-1(3H)one, is a natural phthalideisoquinoline alkaloid obtained from the opium poppy which has been used for many decades as a very safe cough suppressant with no side effects $[1,2]$. Unlike other alkaloids, noscapine is not addictive. Recently, antitumor properties of noscapine have been reported by Joshi's group for the first time [3] and research on the therapeutic effect of noscapine in inhibiting tumor progression in experimental animals is ongoing [4-6]. Moreover, histological studies have shown that noscapine is not toxic to normal tissues [1, 7, 8]. Generally, alkaloids are obtained from opium poppy, are structurally complex, and most of them cannot be economically synthesized. Noscapine has an excellent pharmacological profile, therefore the pure yield of this alkaloid from natural plants is very important.

Isolation of noscapine from opium was studied in literature. Sim showed the separation of alkaloids from opium in a step-wise process and produced noscapine as the last product [9]. Also Ramanathan and Chandra report several processes for purifying narcotine which is known as an impure form of "Noscapine" [10]. In these methods are used opium as the starting material.

On the other hand, the poppy straw is an alternative source which is chemically used to extract the alkaloids [11]. For this method, the capsules of $P$. somniferum are cut and dried in air in the field then harvested and crushed to straw. In many countries this method is present as an alternative route to obtain alkaloids like noscapine due to the fact that the usage of crude opium which contains the controlled substance morphine may be limited by governmental rules. Because of this restriction, noscapine producers have been searching for a new source and poppy straw, which is harvested when it is fully mature and dry, which is suitable for this. Also, it is important to say that poppy straw may contain much higher quantities of noscapine relative to morphine content [12]. However, P. somniferum has been 
<smiles>COc1ccc2c(c1OC)C(=O)OC2[C@@H]1NCCc2cc3c(c(OC)c21)OCO3</smiles>

FIGURE 1: Chemical structure of noscapine.

genetically modified by gene insertion to either enhance alkaloid production or to "switch off" the genes responsible for production of nonrequired alkaloids.

A simple process for isolating the alkaloids is highly desirable to evaluate product quality. This paper describes a method for the extraction and purification of noscapine that is present in the poppy straw. In this method, noscapine was obtained in purity suitable for use in pharmacopy (99.59\%). The chemical structure of this alkaloid is shown in Figure 1.

\section{Experimental}

2.1. General. Melting point was determined in open glass capillary tube by means of a BUCHI Melting Point B540 apparatus. Infrared (FT-IR) spectra were taken using a PerkinElmer Spectrum One FT-IR spectrometer, $v_{\max }$ in $\mathrm{cm}^{-1}$. The ${ }^{1} \mathrm{H}$ and ${ }^{13} \mathrm{C}$ nuclear magnetic resonance (NMR) were taken with a Bruker 500 NMR spectrometer. Chemical shifts are reported in $\mathrm{ppm}(\delta)$. High resolution electrospray ionization mass spectra (HR-ESI-MS) were obtained with $\mathrm{MeOH}$ on a Bruker micrOTOF-Q. Elemental analyses (EA) were performed using a Thermo Finnigan FLASH 1112 SERIES EA instrument. The specific rotation was measured on an Optical Activity Ltd. A55 polarimeter instrument using $2 \mathrm{~cm}^{3}$ cell with a $0.5 \mathrm{dm}$ path length and the sample concentration is given in $\mathrm{g} / 100 \mathrm{~cm}^{3}$ unit. Chemical reagents for isolation were of analytical grade and purchased from Merck (Darmstadt, 90 Germany). All solvents were filtered through $0.45 \mu \mathrm{m}$ membrane filters before being injected into the HPLC.

2.2. Plant Material. Poppy capsules were procured from Turkish Grain Board in August 2009. For this method, the capsules of $P$. somniferum are cut and dried in air in the field then harvested and crushed to straw. These capsules are grown from genetically engineered seeds and contain 1.5\% $(\mathrm{w} / \mathrm{w})$ noscapine.

2.3. Extraction of Crude Noscapine. A three-neck round bottom flask was charged with $500 \mathrm{~g}$ of air-dried and ground poppy straw, $2000 \mathrm{~cm}^{3}$ of ethanol, and $250 \mathrm{~cm}^{3}$ of demineralised water. The contents of the flask were stirred mechanically. The suspension was heated and refluxed for two hours at $80-85^{\circ} \mathrm{C}$. The suspension was filtered. The alcohol extract was concentrated under reduced pressure to give $200 \mathrm{~cm}^{3}$ of brown aqua phase. The $\mathrm{pH}$ of the solution was set 3.5 by adding acetic acid. $5.0 \mathrm{~g}$ of activated charcoal were added into this solution and contents was heated to $60^{\circ} \mathrm{C}$ and stirred mechanically for fifteen minutes. This solution was filtered. The filtrate was extracted with chloroform (4 times $250 \mathrm{~cm}^{3}$ ) and the extracts are combined. The chloroform extract was concentrated to give $15 \mathrm{~g}$ of dark brown residue. This residue was dissolved in $400 \mathrm{~mL}$ of $10 \%$ acetic acid solution and heated to $50^{\circ} \mathrm{C}$. The $\mathrm{pH}$ of this solution was made 9.3 by adding $25 \%$ ammonia slowly. Crude noscapine was precipitated. The precipitate was filtered and dried in an oven at $105^{\circ} \mathrm{C}$.

2.4. Purification of Crude Noscapine. Crude noscapine was suspended in $50 \mathrm{~cm}^{3}$ of toluene. The suspension was heated to $70-80^{\circ} \mathrm{C} .5 .0 \mathrm{~g}$ of activated charcoal was added and stirred mechanically for fifteen minutes at room temperature. The solution was filtered. The filtrate was concentrated under reduced pressure to give white precipitate and stirred mechanically for thirty minutes in an ice bath. The white precipitate was filtered and dried in an oven at $105^{\circ} \mathrm{C}$. The resulting white solid corresponded to a yield of $90 \%$ and purity (by HPLC) of $99.59 \%$. M.p.: $174-177^{\circ} \mathrm{C}$ (decomp); $[\alpha]_{D}^{22}=-176^{\circ}\left(c=0.5 \mathrm{~g} / 100 \mathrm{~cm}^{3}, \mathrm{CHCl}_{3}\right) .{ }^{1} \mathrm{H}$ NMR $(500$ $\left.\mathrm{MHz}, \mathrm{CDCl}_{3}\right): \delta=1.88-1.93(\mathrm{~m}, 1 \mathrm{H}), 2.32-2.38(\mathrm{~m}, 2 \mathrm{H})$, $2.55(\mathrm{~s}, 3 \mathrm{H}), 2.58-2.61(\mathrm{~m}, 1 \mathrm{H}), 3.86(\mathrm{~s}, 3 \mathrm{H}), 4.05(\mathrm{~s}, 3 \mathrm{H}), 4.09$ $(\mathrm{s}, 3 \mathrm{H}), 4.40(\mathrm{~d}, J=3.8 \mathrm{~Hz}, 1 \mathrm{H}), 5.58(\mathrm{~d}, J=3.8 \mathrm{~Hz}, 1 \mathrm{H}), 5.94$ $(\mathrm{s}, J=1.2 \mathrm{~Hz}, 1 \mathrm{H}), 6.08(\mathrm{~d}, J=8.2 \mathrm{~Hz}, 1 \mathrm{H}), 6.31(\mathrm{~s}, 1 \mathrm{H}), 6.96$ $(\mathrm{d}, J=8.2 \mathrm{~Hz}, 1 \mathrm{H}) ;{ }^{13} \mathrm{C}$ NMR $\left(125 \mathrm{MHz}, \mathrm{CDCl}_{3}\right): \delta=28.0$ $(\mathrm{t}), 46.3(\mathrm{q}), 50.0(\mathrm{t}), 56.9(\mathrm{~d}), 59.4(\mathrm{~d}), 60.9(\mathrm{~d}), 62.2(\mathrm{~d}), 81.8$ (d), 100.7 (t), 102.3 (d), 117.2 (s), 117.6 (d), 118.4 (d), 120.2 (s), $132.1(\mathrm{~s}), 134.1(\mathrm{~s}), 140.5(\mathrm{~s}), 141.3(\mathrm{~s}), 147.9(\mathrm{~s}), 148.4(\mathrm{~s})$, $152.2(\mathrm{~s}), 168.0(\mathrm{~s})$.

\subsection{Determination of Alkaloid Content of Poppy Capsule, Crude Noscapine and Pure Noscapine by HPLC}

2.5.1. Sample Preparation. $200 \mathrm{mg}$ of homogenized, powdered, dried poppy capsule was shaken with $50.0 \mathrm{~cm}^{3} 0.1 \mathrm{M}$ hydrochloric acid for 2 hours. An aliquot of the extract was filtrated and the filtrate was filled to a vial.

$50 \mathrm{mg}$ of crude noscapine or pure noscapine was dissolved in $5 \mathrm{~cm}^{3}$ of $10 \%$ acetic acid solution is added approximately and $100 \mathrm{~cm}^{3}$ of demineralised water, sonicated to dissolve, then diluted to $250 \mathrm{~cm}^{3}$ with demineralised water. It was mixed well and filled to a vial.

2.6. Chromatographic System. An Agilent 1200 HPLC with UV-vis detection capabilities and a $0.01 \mathrm{~cm}^{3}$ injection volume was used. The wavelength used during the analysis was $288 \mathrm{~nm}$. A Eurospher-100 column (KNAUER) measuring $120 \times 4 \mathrm{~mm}, 5 \mu \mathrm{m}$ particle size and with C18 stationary phase was used. The column was heated and maintained at $40^{\circ} \mathrm{C}$. The mobile phases consisted of $(\mathrm{A})$ water with $0.67 \%$ trifluoroacetic acid (TFA) and (B) $0.67 \%$ TFA in a mixture of methanol, acetonitrile, and water $\left(500 / 16 / 129 \mathrm{~cm}^{3}\right)$ using a gradient system. The flow rate was $1.0 \mathrm{~mL} / \mathrm{min}$ and the applied elution program is described in Table 1. 
TABLE 1: Parameters of gradient elution program.

\begin{tabular}{lccc}
\hline Time $(\mathrm{min})$ & Flow rate $\left(\mathrm{cm}^{3} / \mathrm{min}\right)$ & Eluent A (v/v) & Eluent B (v/v) \\
\hline 0.0 & 1.0 & 84.0 & 16.0 \\
14.4 & 1.0 & 45.2 & 54.8 \\
14.5 & 1.0 & 0.0 & 100.0 \\
16.4 & 1.0 & 0.0 & 16.0 \\
16.5 & 1.0 & 84.0 & 16.0 \\
\hline
\end{tabular}

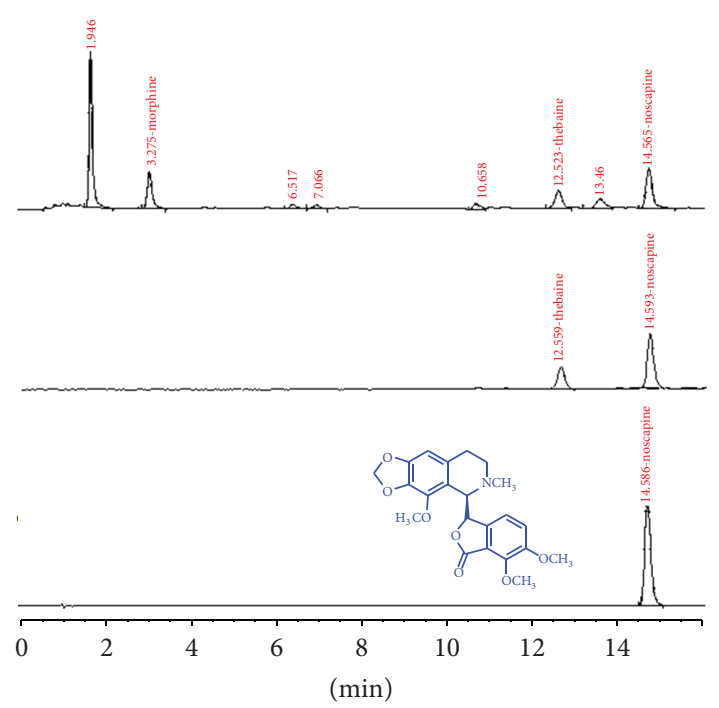

FIGURE 2: HPLC chromatograms of step by step noscapine isolation and purification (a) alkaloids in poppy straw sample. (b) Chromatogram of crude noscapine (the crude extract contains $49.411 \%$ noscapine) after extraction process. (c) Chromatogram of pure (99.59\%) noscapine.

\section{Results and Discussion}

Noscapine was isolated as a white crystalline solid with negative rotation $[\alpha]_{D}^{22}=-176^{\circ}\left(c=0.5 \mathrm{~g} / 100 \mathrm{~cm}^{3}, \mathrm{CHCl}_{3}\right)$. Several elution systems were tested in HPLC separation. The results indicated that when methanol-acetonitrile-water was used as mobile phase in gradient mode (Table 1), good seperation results could be obtained. HPLC analysis of poppy straw, crude extract, and pure noscapine show that noscapine was clearly seperated and exhibited well-defined chromatogram with retention times of $14.586 \mathrm{~min}$ in the selected experimental conditions (Figure 2). The content of noscapine in the crude extracts was $49.4 \%$. After purification treatment, the purity of the collected fraction peak 1 was found to be $99.59 \%$.

Its molecular formula was determined as $\mathrm{C}_{22} \mathrm{H}_{23} \mathrm{NO}_{7}$ on the basis of HR-ESI-MS $\left(m / z 414.1553\left[\mathrm{M}^{+} \mathrm{H}\right]^{+}\right.$, calcd for $\mathrm{C}_{22} \mathrm{H}_{23} \mathrm{NO}_{7}$ 414.1532). Figure 3 shows the expected molecular ion peak at $m / z=414.1553$, indicating formation of $\left[\mathrm{M}^{+} \mathrm{H}\right]^{+}$.

The chemical structure of peak fraction in Figure 2(c) was identified according to its FT-IR, ${ }^{1} \mathrm{H}$ NMR data ${ }^{13} \mathrm{C}$ NMR. These were well-matched with the literature [12-15]. Figure 4 shows infrared spectra of pure noscapine product and

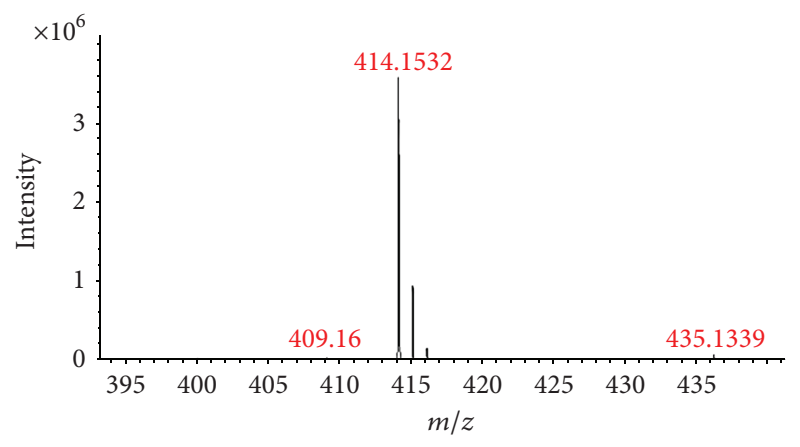

FIGURE 3: HR-ESI-MS data of pure noscapine product.

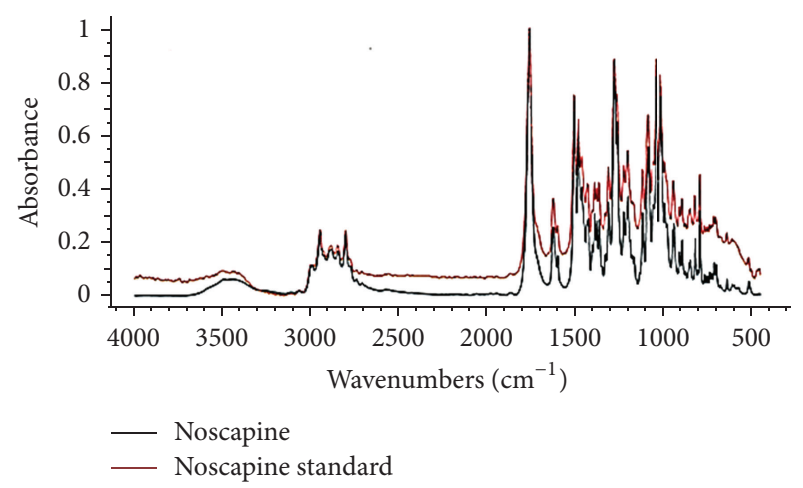

FIGURE 4: FT-IR spectrums of noscapine product and noscapine standard (purchased from Turkish Grain Board).

noscapine standard (purchased from Turkish Grain Board). IR spectra show numerous sharp bands between 700 and $1500 \mathrm{~cm}^{-1}$ which are assigned to deformation and stretching vibrations of the alkaloid ring system. Also, the strong band at $1756 \mathrm{~cm}^{-1}$ is the most characteristic for $\mathrm{C}=\mathrm{O}$ stretching vibration.

The NMR spectrum of noscapine shows two one-proton doublets at 6.96 and $6.08 \mathrm{ppm}$ assigned to the aromatic protons in the phthalidyl ring. The one-proton singlet signal at $6.31 \mathrm{ppm}$ is attributed to aromatic proton in the isoquinoline ring. The three-proton singlets at $3.86 \mathrm{ppm}, 4.05$, and $4.09 \mathrm{ppm}$ are ascribed to methoxy protons in isoquinoline and phthalidyl rings, respectively. The signal at 5.94 which is given as a two-proton singlet is accounted the methylenedioxy protons. The singlet signal at $2.55 \mathrm{ppm}$ is due to the $-\mathrm{N}-\mathrm{CH}_{3}$ protons. The $-\mathrm{CH}_{2}-\mathrm{CH}_{2}-$ protons of isoquinoline ring are appeared as a multiplet at $2.32-2.38 \mathrm{ppm}$.

The ${ }^{13} \mathrm{C}$ NMR spectrum of compound exhibited signals for aromatic carbons between 117.2-134.1 ppm, methylenedioxy carbon at $100.7 \mathrm{ppm}$, and carbonyl carbon at 168.0 ppm. The signals at 56.9, 59.4, and $62.2 \mathrm{ppm}$ are ascribed to methoxy carbon atoms. The carbon atom which bonded nitrogen atom is observed at $46.3 \mathrm{ppm}$.

\section{Conclusions}

Prior to now, noscapine is isolated from opium. Recently, following seed development and gene studies, poppy seed 
including capsules that are rich in noscapine have been developed. To our knowledge, this is the first report on the isolation of noscapine from poppy capsules. The isolation method is very short compared with other production methods from opium. Hence, poppy straw could be used as an accessible source of noscapine product with high yield. Its chemical structure was clearly confirmed by using various instrumental techniques. The obtained product has pharmacological purity and does not include impurities.

\section{References}

[1] B. Dahlstrom, T. Mellstrand, C. G. Lofdahl, and M. Johansson, "Pharmacokinetic properties of noscapine," European Journal of Clinical Pharmacology, vol. 22, no. 6, pp. 535-539, 1982.

[2] J. E. Idänpään-Heikkilä, K. Jalonen, and A. Vartiainen, "Evaluation of the antitussive effect of noscapine and codeine on citric acid cough in guinea-pigs," Acta Pharmacologica et Toxicologica, vol. 25, pp. 333-338, 1967.

[3] K. Ye, Y. Ke, N. Keshava et al., "Opium alkaloid noscapine is an antitumor agent that arrests metaphase and induces apoptosis in dividing cells," Proceedings of the National Academy of Sciences of the United States of America, vol. 95, no. 4, pp. 1601-1606, 1998.

[4] M. Chougule, A. R. Patel, P. Sachdeva, T. Jackson, and M. Singh, "Anticancer activity of Noscapine, an opioid alkaloid in combination with Cisplatin in human non-small cell lung cancer," Lung Cancer, vol. 71, no. 3, pp. 271-282, 2011.

[5] R. Aneja, S. N. Vangapandu, M. Lopus, R. Chandra, D. Panda, and H. C. Joshi, "Development of a novel nitro-derivative of noscapine for the potential treatment of drug-resistant ovarian cancer and T-cell lymphoma," Molecular Pharmacology, vol. 69, no. 6, pp. 1801-1809, 2006.

[6] T. Jackson, M. B. Chougule, N. Ichite, R. R. Patlolla, and M. Singh, "Antitumor activity of noscapine in human non-small cell lung cancer xenograft model," Cancer Chemotherapy and Pharmacology, vol. 63, no. 1, pp. 117-126, 2008.

[7] D. W. Empey, L. A. Laitinen, G. A. Young, C. E. Bye, and D. T. Hughes, "Comparison of the antitussive effects of codeine phosphate $20 \mathrm{mg}$, dextromethorphan $30 \mathrm{mg}$ and noscapine $30 \mathrm{mg}$ using citric acid-induced cough in normal subjects," European Journal of Clinical Pharmacology, vol. 16, pp. 393-397, 1979.

[8] M. O. Karlsson, B. Dahlstrom, S. A. Eckernas, M. Johansson, and A. T. Alm, "Pharmacokinetics of oral noscapine," European Journal of Clinical Pharmacology, vol. 39, no. 3, pp. 275-279, 1990.

[9] S. K. Sim, Medicinal Plant Alkaloids, Toronto Press, 2nd edition, 1970.

[10] V. S. Ramanathan and P. Chandra, "Recovery, separation and purification of narcotine and papaverine from Indian opium," Bulletin on Narcotics, vol. 33, no. 1, pp. 55-63, 1981.

[11] I. Bayer, "Manufacture of alkaloids from the poppy plant in Hungary," Bulletin on Narcotics, vol. 13, no. 1, pp. 21-28, 1961.

[12] M. A. Al-Yahya and M. M. A. Hassan, "Noscapine," Analytical Profiles of Drug Substances and Excipients, vol. 11, pp. 407-461, 1982.

[13] British Pharmacopoeia Commission, The British Pharmacopoeia 2011, Her Majesty's Stationary Office, London, UK, 2011.
[14] H. Schulz, M. Baranska, R. Quilitzsch, and W. Schütze, "Determination of alkaloids in capsules, milk and ethanolic extracts of poppy (Papaver somniferum L.) by ATR-FT-IR and FT-Raman spectroscopy," Analyst, vol. 129, no. 10, pp. 917-920, 2004.

[15] R. L. Prasad, S. N. Thakur, and G. C. Bhar, " $\mathrm{CO}_{2}$ laser photoacoustic spectra and vibrational modes of heroin, morphine and narcotine," Pramana, vol. 59, no. 3, pp. 487-496, 2002. 

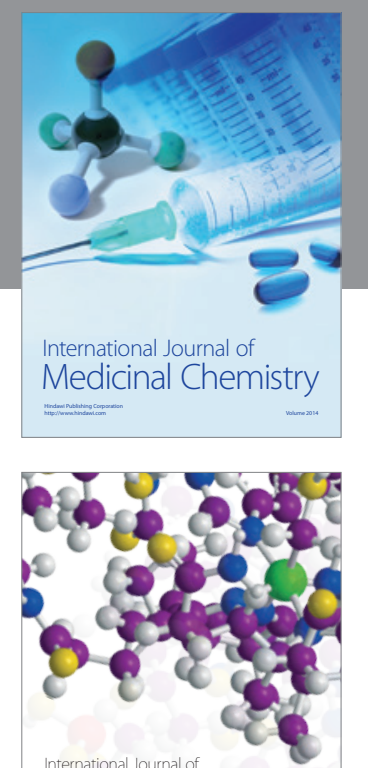

\section{Carbohydrate} Chemistry

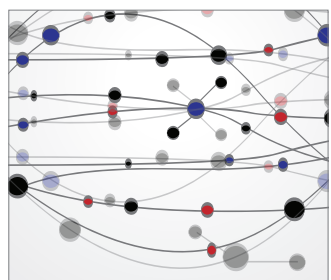

The Scientific World Journal
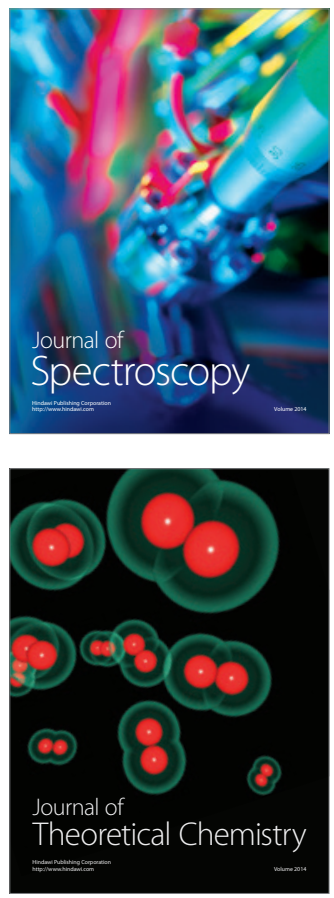
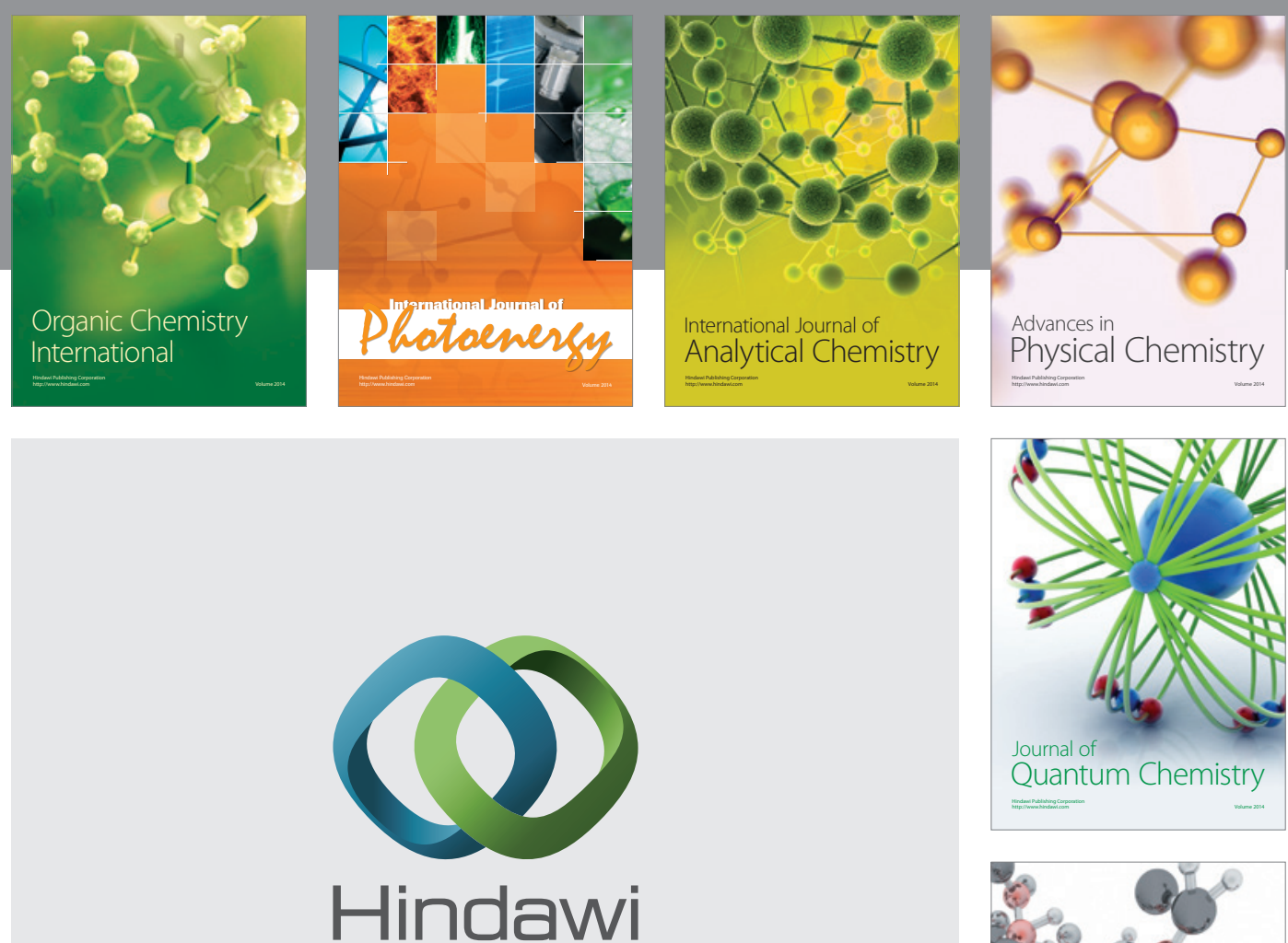

Submit your manuscripts at

http://www.hindawi.com

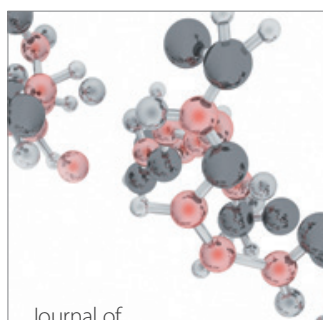

Analytical Methods

in Chemistry

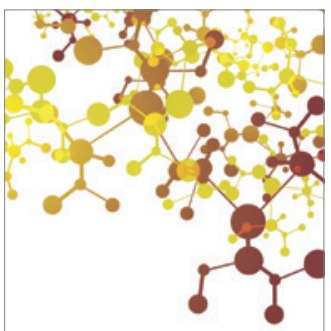

Journal of

Applied Chemistry

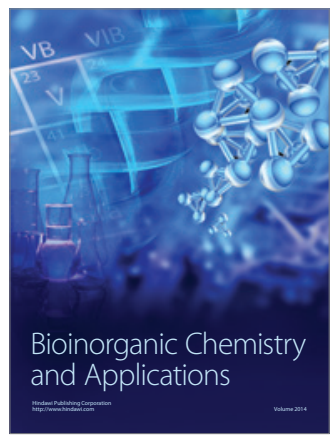

Inorganic Chemistry
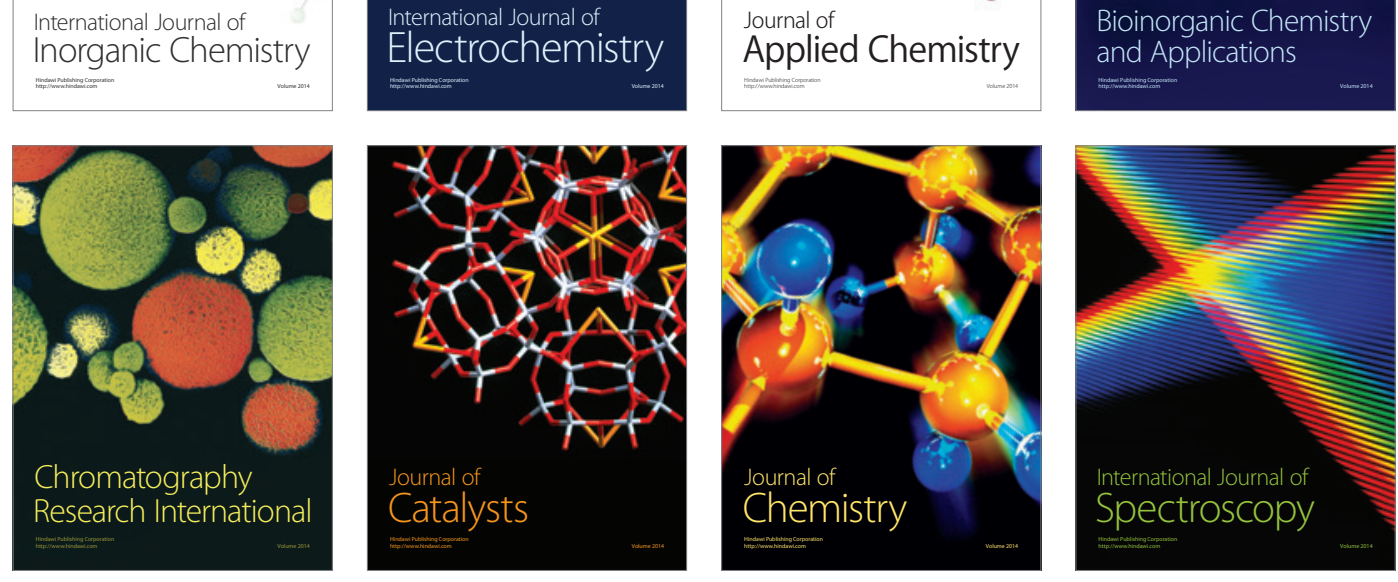